\title{
Assessment of Air Quality Changes in the Four Metropolitan Cities of India during COVID-19 Pandemic Lockdown
}

\author{
Jasbir Singh Bedi*, Pankaj Dhaka, Deepthi Vijay, Rabinder Singh Aulakh, \\ Jatinder Paul Singh Gill
}

\author{
School of Public Health and Zoonoses, College of Veterinary Science, Guru Angad Dev Veterinary and Animal Sciences \\ University, Ludhiana 141004, India
}

\begin{abstract}
In view of emerging threat of COVID-19 pandemic, stringent lockdown measures have been implemented in India since $25^{\text {th }}$ March, 2020. The present study aims to assess the changes in air quality before and during lockdown in the four major metropolitan cities of India viz., Delhi, Mumbai, Kolkata and Chennai. The data on major air quality parameters and meteorological parameters was collected for 15 days before lockdown (i.e., March $10^{\text {th }}-$ March $24^{\text {th }}$, 2020) and 15 days after implementation of lockdown (25 $5^{\text {th }}$ March-April $\left.8^{\text {th }}, 2020\right)$. The lockdown measures reflected a significant reduction in air pollutants, most significant fall was estimated for $\mathrm{NO}_{2}(29.3-74.4 \%)$ while the least reduction was noticed for $\mathrm{SO}_{2}$. On the contrary, levels of ground level ozone were found to be increased (except in Mumbai), could be related to the lower utilization of $\mathrm{O}_{3}$ owing to decrease of $\mathrm{NO}_{x}$ in the environment. Since, the lockdown period has been extended, therefore further reduction of most pollutants is expected. Among the various metrological parameters, significant increase in diurnal temperature was observed at Delhi, Kolkata and Mumbai, however relative humidity has changed significantly only in Mumbai. In the absence of any major violent meteorological phenomena in India during recent months the significant difference in air quality parameters could be majorly attributed to the effect of lockdown measures. However, the regional differences may be because of the local emission of pollutants and the prevailing effects of secondary pollutants. These observations highlight the contribution of anthropogenic sources in air pollution, therefore, sustainable polices for mitigation of air pollution are essential in India.
\end{abstract}

Keywords: Air Pollution; Air Quality; COVID-19; India; Lockdown; Metropolitan cities.

\section{INTRODUCTION}

Air pollution remains one of the most important public health concerns across the globe, contributing substantial premature mortality with greater impact in developing nations (Mannucci and Franchini, 2017; Barzeghar et al., 2020). As per World Health Organization (WHO), it has been estimated that 4.2 million premature deaths globally are linked to ambient air pollution. The pollutants with the strongest evidence for public health concern include particulate matter $\left(\mathrm{PM}_{2.5}\right.$ and $\left.\mathrm{PM}_{10}\right)$, nitrogen dioxide $\left(\mathrm{NO}_{2}\right)$, sulphur dioxide $\left(\mathrm{SO}_{2}\right)$ and ozone $\left(\mathrm{O}_{3}\right)$ (WHO, 2020a).

India being the second most populous country of the world, is severely burdened with the hazardous effects of air pollution. In a recent study, a mortality of 1.2 million and 38.7 million disability-adjusted life-years (DALYs) has been found to be associated with air pollution in India (Balakrishnan et al.,

\footnotetext{
* Corresponding author.

E-mail address: bedijasbir78@gmail.com
}

2019). As per the 'World Air Quality report-2019' on the basis of particulate matter $\left(\mathrm{PM}_{2.5}\right)$, India ranks the fifth most polluted country in the world and dominated the list of the smoggiest urban areas, where 21 of the top 30 most polluted cities were from India (IQAir, 2019). Owing to increasing industrialization across the country, progressive worsening of ambient air pollution remains a great challenge for sustainable development and public health reforms (Gordon et al., 2018).

In the dawn of 2020, the world was threatened by the pandemic of COVID-19, caused by a novel infectious virus of the coronavirus family, SARS-CoV-2. It started as a cluster of viral pneumonia cases in Wuhan, China and had an unprecedented spread all over the world. As on May $6^{\text {th }}$, 2020, the SARS-CoV-2 pandemic has resulted in 3,588,773 cases and 2,47,503 deaths globally, wherein, a total of 49,391 cases and 1,694 deaths were reported from India (WHO, 2020b). India, with a population of 1.3 billion, has entered into a nationwide lockdown on $25^{\text {th }}$ March, 2020, to break the chain of coronavirus transmission. The lockdown measures primarily focused on flattening the epidemic curve by restricting the social contact which include closure of 
public transport including railways and roadways, shutting down of international and domestic air travels and closing industries and businesses, except for essential public services.

The global scientific reports are coming up on the effect of COVID-19 related lockdowns or reduced anthropogenic activities and changes in air quality parameters (Chen et al., 2020; Muhammad et al., 2020; Tobías et al., 2020; Xu et al., 2020). In India, the effect of lockdown on air quality have been majorly discussed in print media reports, however, scientific publication remains limited (Jain and Sharma, 2020; Mahato et al., 2020; Sharma et al., 2020). In this context, the present study aims to assess the changes in air quality parameters during the implementation of the lockdown measures in the four major metropolitan cities of India, viz., Delhi, Mumbai, Kolkata and Chennai for a one-month period ( 15 days before lockdown and 15 days after the implementation of lockdown). The meteorological parameters were also assessed during this period to observe any significant natural climatic deviations, if any.

\section{METHODS}

In present study, four major metropolitan cities of India, viz., Delhi, Mumbai, Kolkata and Chennai, were included to assess the air quality parameters. The rationale behind the selection of these cities was their high population with a total of more than 30 million (CensusInfo India, 2011) as well as distant locations which represent the four major geographical divisions of the country, thereby to reduce the regional biasness in study.

The official lockdown in India was enforced on $25^{\text {th }}$ March, 2020. Therefore, the data was collected in two phases, 15 days before the lockdown (i.e., March $10^{\text {th }}-$ March $24^{\text {th }}$ ) and 15 days after the lockdown (25 $5^{\text {th }}$ March-April $\left.8^{\text {th }}, 2020\right)$ implementation from these targeted cities. The daily air quality data was obtained from the data repository maintained by Central Pollution Control Board (CPCB) under the Ministry of Environment, Forest and Climate Change, India (https://app.cpcbccr.com/AQI_India/). The targeted data stations were Delhi (Anand Vihar: $28.6502^{\circ} \mathrm{N}$, $77.3027^{\circ} \mathrm{E}$ ), Mumbai (Bandra: $19.0596^{\circ} \mathrm{N}, 72.8295^{\circ} \mathrm{E}$ ), Kolkata (Ballygunge: $22.5280^{\circ} \mathrm{N}, 88.3659^{\circ} \mathrm{E}$ ) and Chennai (Manali Village: $13.1779^{\circ} \mathrm{N}, 80.2701^{\circ} \mathrm{E}$ ) and the timing selected for the data recording was 10:00 am. The air quality data was included for particulate matter with diameter less than 2.5 microns $\left(\mathrm{PM}_{2.5}\right)$, particulate matter with diameter less than 10 microns $\left(\mathrm{PM}_{10}\right)$, nitrogen dioxide $\left(\mathrm{NO}_{2}\right)$, ammonia $\left(\mathrm{NH}_{3}\right)$, sulphur dioxide $\left(\mathrm{SO}_{2}\right)$, carbon monoxide $(\mathrm{CO})$ and ground level ozone $\left(\mathrm{O}_{3}\right)$.

In addition, the meteorological parameters of these cities were also recorded for before and during lockdown period in order to assess the variation, if any, with the air quality parameters. In this regard, data about meteorological parameters including temperature $\left({ }^{\circ} \mathrm{C}\right)$, humidity $(\%)$, wind speed $\left(\mathrm{km} \mathrm{hr}^{-1}\right)$ and atmospheric pressure (mbar) were obtained from Time and Date AS, Norway (https://www.tim eanddate.com/weather/). The Remote sensing $\mathrm{NO}_{2}$ data of India was collected for a day in the pre-lockdown phase $\left(15^{\text {th }}\right.$ March, 2020) and a day during lockdown period ( $8^{\text {th }}$ April,
2020). The data images were obtained from Copernicus Sentinel-5 Precursor Tropospheric Monitoring Instrument (S5p/TROPOMI) developed by the European Space Agency (ESA), which has been used to assess tropospheric $\mathrm{NO}_{2}$ background levels in a continuous area (Veefkind et al., 2012).

The mean concentration and percent difference for air quality and meteorological parameters were calculated. The data were found to be normally distributed by Shapiro-Wilk test using SPSS version 24.0 (SPSS Inc., IBM, NY, USA). The significant association between these parameters for a given city before- and after- lockdown period was calculated by using two sample t-test (two-tailed) at $95 \%$ confidence interval by using statistical software, Epitools (Sergeant, 2018). A p-value of $<0.05$ was considered as statistically significant.

\section{RESULTS AND DISCUSSION}

In developing nations, burgeoning human population, high population density, rapid industrialization and increasing urbanization are aggravating the gravity of the air pollution (Mannucci and Franchini, 2017). In India, the enforcement of stringent lockdown measures because of COVID-19 pandemic has brought transport, industries and construction activities to a sudden halt. The retrieved data on air quality parameters of the targeted cities during 'before lockdown' (March 10 $0^{\text {th }}-$ March $24^{\text {th }}, 2020$ ) and 'during lockdown phase' $\left(25^{\text {th }}\right.$ March-April $\left.8^{\text {th }}, 2020\right)$ is summarized for mean concentration and percent difference (Table 1 and Fig. 1) [Details in Table S1]. The meteorological data before and during lockdown phase among targeted cities has been summarized in Table S2.

After two weeks of lockdown, air pollution has significantly decreased with considerable differences in concentration of major pollutants. During the lockdown phase, the average concentration of $\mathrm{PM}_{2.5}$ was found to be significantly ( $\mathrm{p}<$ 0.05 ) reduced by $63.9 \%, 34.5 \%$ and $53.6 \%$ in Delhi, Mumbai and Kolkata, respectively. On contrary, the concentration was slightly increased by $8.8 \%$ (non-significant) in Chennai. The mean concentration of $\mathrm{PM}_{2.5}$ during lockdown was still observed to be above the recommended Air Quality Guideline of World Health Organization (WHO), i.e., daily reference value of $25 \mu \mathrm{g} \mathrm{m}^{-3}$ for $\mathrm{PM}_{2.5}$ (WHO, 2018). The increase in $\mathrm{PM}_{2.5}$ concentration in Chennai can be attributed to the difference in meteorological parameters, especially in terms of precipitation. Rainfall has been considered as an important factor for reducing the concentration and washing out of various atmospheric pollutants (Elperin et al., 2011; Guo et al., 2016). During the present study, the North-West India, Central India and East India have received rainfall, on contrary, the Southern peninsula where Chennai is located, received scanty rainfall during this period (Skymet Weather Team, 2020).

Similarly, a significant reduction $(\mathrm{p}<0.05)$ in the average concentration of $\mathrm{PM}_{10}$ was observed in Delhi $(56.7 \%)$ followed by Kolkata (34.2\%), whereas, a non-significant reduction was found in Mumbai $(20.1 \%)$. However, all the reduced concentrations during the lockdown were still 
Table 1. Average Air quality parameters before and during lockdown phase among four major metropolitan cities of India.

\begin{tabular}{|c|c|c|c|c|c|c|c|c|}
\hline & \multicolumn{4}{|c|}{ Delhi } & \multicolumn{4}{|c|}{ Mumbai } \\
\hline $\begin{array}{l}\text { Air Quality } \\
\text { parameters }\end{array}$ & $\begin{array}{l}\text { Before } \\
\text { lockdown }\end{array}$ & $\begin{array}{l}\text { During } \\
\text { lockdown }\end{array}$ & $\begin{array}{l}\text { Difference } \\
\left(\mu \mathrm{g} \mathrm{m}^{-3}\right)\end{array}$ & $\begin{array}{l}\% \\
\text { Difference }\end{array}$ & $\begin{array}{l}\text { Before } \\
\text { lockdown }\end{array}$ & $\begin{array}{l}\text { During } \\
\text { lockdown }\end{array}$ & $\begin{array}{l}\text { Difference } \\
\left(\mu \mathrm{g} \mathrm{m}^{-3}\right)\end{array}$ & $\begin{array}{l}\% \\
\text { Difference }\end{array}$ \\
\hline $\mathrm{PM}_{2.5}$ & 151.8 & 54.8 & 97.0 & $63.9^{*}$ & 47.4 & 31.0 & 16.4 & $34.5^{*}$ \\
\hline $\mathrm{PM}_{10}$ & 166.0 & 71.9 & 94.1 & $56.7^{*}$ & 80.9 & 64.7 & 16.2 & 20.1 \\
\hline $\mathrm{NO}_{2}$ & 60.6 & 21.9 & 38.7 & $63.9^{*}$ & 69.2 & 17.7 & 51.5 & $74.4^{*}$ \\
\hline $\mathrm{NH}_{3}$ & 6.4 & 5.2 & 1.2 & 18.2 & NA & NA & NA & NA \\
\hline $\mathrm{SO}_{2}$ & 13.4 & 12.0 & 1.2 & 8.9 & 22.1 & 29.3 & -7.2 & $-32.5^{*}$ \\
\hline $\mathrm{CO}$ & 91.4 & 61.3 & 29.8 & $32.7^{*}$ & 80.2 & 48.1 & 32.1 & $40.1^{*}$ \\
\hline Ozone & 30.1 & 45.4 & -15.3 & $-50.9^{*}$ & 36.0 & 19.9 & 16.1 & $44.8^{*}$ \\
\hline & \multicolumn{4}{|c|}{ Kolkata } & \multicolumn{4}{|c|}{ Chennai } \\
\hline $\mathrm{PM}_{2.5}$ & 137.7 & 63.9 & 73.8 & $53.6^{*}$ & 27.0 & 29.4 & -2.4 & -8.8 \\
\hline $\mathrm{PM}_{10}$ & 109.5 & 72.0 & 37.5 & $34.2^{*}$ & 43.2 & NA & NA & NA \\
\hline $\mathrm{NO}_{2}$ & 28.1 & 9.6 & 18.5 & $65.8^{*}$ & 10.2 & 7.2 & 3.0 & $29.3^{*}$ \\
\hline $\mathrm{NH}_{3}$ & 2.9 & 2.0 & 0.9 & $31.5^{*}$ & 15.6 & 13.7 & 1.9 & 12.1 \\
\hline $\mathrm{SO}_{2}$ & 10.7 & 8.2 & 2.4 & $22.8^{*}$ & 9.1 & 8.7 & 0.5 & $5.0^{*}$ \\
\hline $\mathrm{CO}$ & 23.5 & 16.8 & 6.7 & $28.5^{*}$ & 17.3 & 21.5 & -4.2 & $-24.1^{*}$ \\
\hline Ozone & 40.2 & 42.8 & 2.5 & -6.3 & 100.9 & 119.8 & -18.9 & $-18.8 *$ \\
\hline
\end{tabular}

* Statistical significance $(\mathrm{p}<0.05)$.
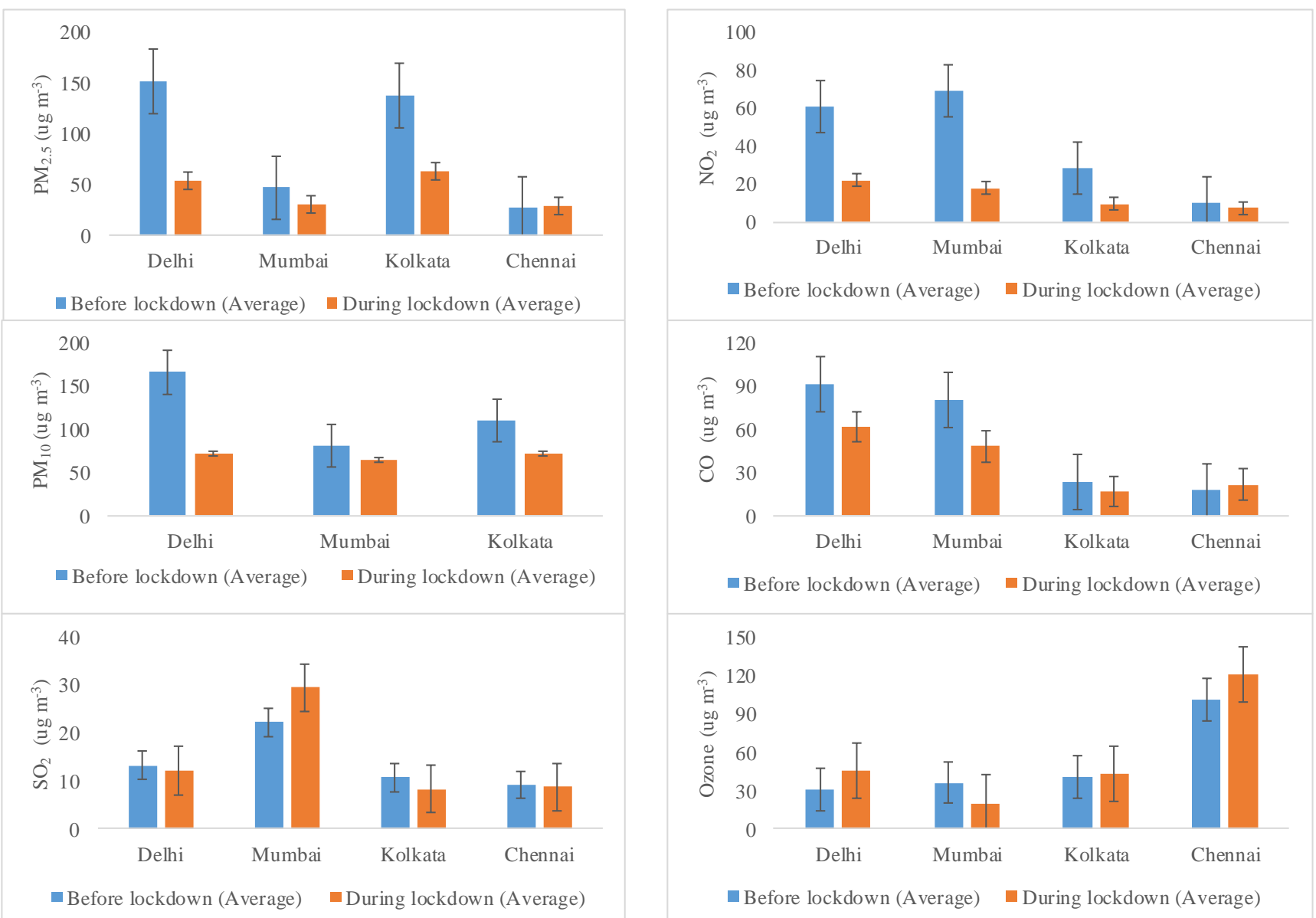

Fig. 1. Average air quality parameters before lockdown and during lockdown periods in four metropolitan cities of India.

higher than WHO daily reference value of $50 \mu \mathrm{g} \mathrm{m}{ }^{-3}$ for $\mathrm{PM}_{10}$. The data on $\mathrm{PM}_{10}$ concentration was insufficient to be summarized for the Chennai station.

The main sources of $\mathrm{PM}_{2.5}$ and $\mathrm{PM}_{10}$ are road traffic, industrial emissions, biomass burning, construction works and dust re-suspension (Sharma and Mandal, 2017). The significant reduction of $\mathrm{PM}_{2.5}$ and $\mathrm{PM}_{10}$ average concentrations evidenced the closure of such activities, however, the 
variation of these particulate matters in the different urban environments, could be because of difference in source of particulate matter, local geography and meteorological conditions (Marlier et al., 2016). In concordance with the observed findings, a $10 \%$ reduction in the average level of particulate matter pollution was observed during the one month of lockdown in Europe (CREA, 2020), while in Barcelona (Spain) the reduction of $\mathrm{PM}_{10}$ varied from 28 to $31 \%$ (Tobias et al., 2020). However, during COVID-19 pandemic due to excess use of private vehicles in Iran to avoid the social contact resulted in worsening of the ambient particulate matter quality (Faridi et al., 2020).

The significant reduction $(\mathrm{p}<0.05)$ in the mean concentration of $\mathrm{NO}_{2}$ was observed in all the four cities, with highest reduction noticed in Mumbai (74.4\%). It is noteworthy that the levels of $\mathrm{NO}_{2}$ concentrations for all the cities were found below the WHO limits (i.e., $40 \mu \mathrm{g} \mathrm{m}^{-3}$ annual mean) after implementation of lockdown. Moreover, the remote sensing $\mathrm{NO}_{2}$ data images of India, obtained from Copernicus Sentinel-5 Precursor Tropospheric Monitoring Instrument (S5p/TROPOMI), for a day in the pre-lockdown phase $\left(15^{\text {th }}\right.$ March, 2020) and during lockdown period $\left(8^{\text {th }}\right.$ April, 2020) displayed visual differences in the tropospheric $\mathrm{NO}_{2}$ background levels in all the four selected cities (Fig. 2). The decrease in $\mathrm{NO}_{2}$ levels can be attributed to the substantial reduction in emissions mainly from transport sector and industrial processes. $\mathrm{NO}_{2}$ is also an intermediate in the industrial synthesis of nitric acid, which is primarily used for

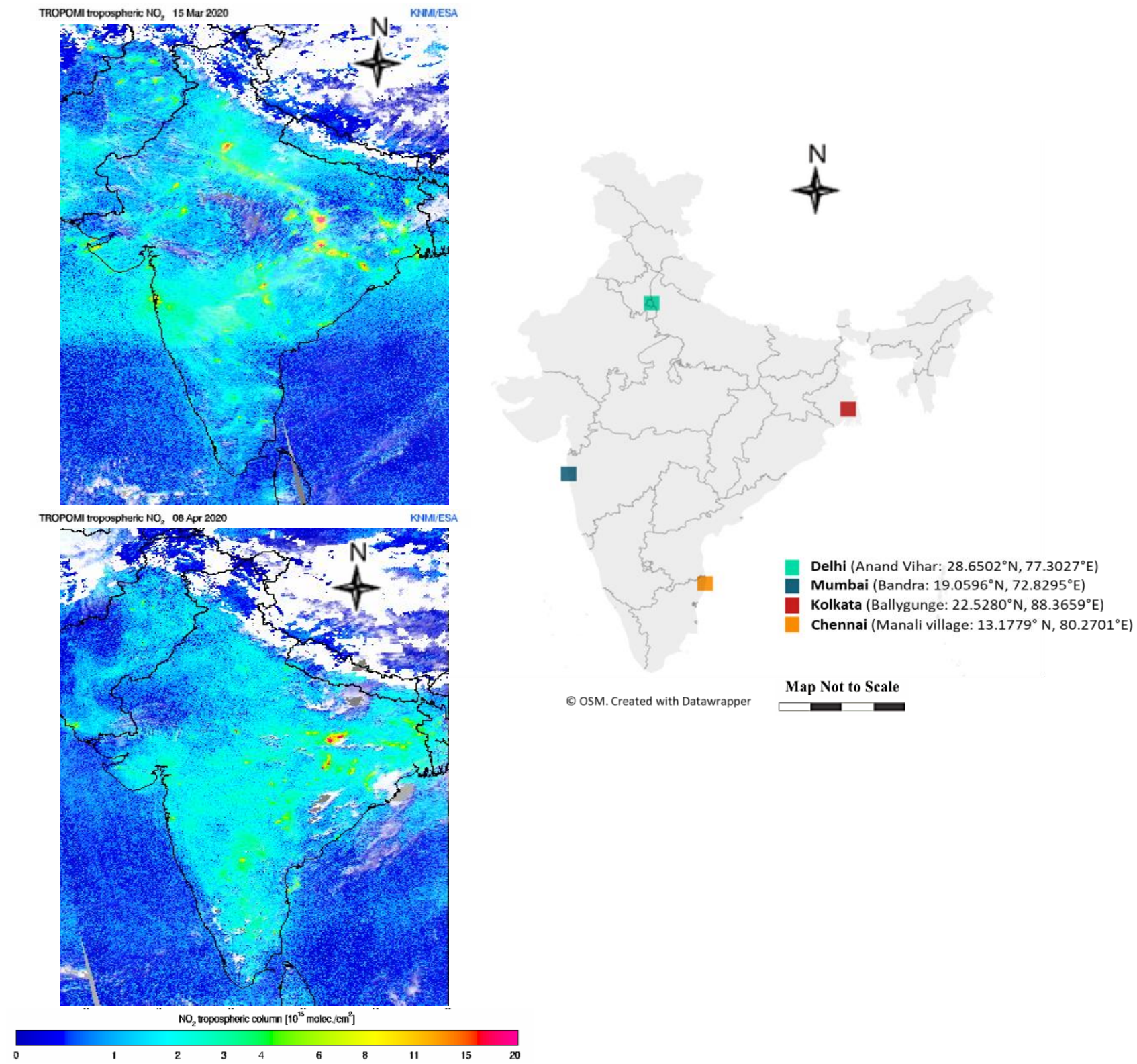

Fig. 2. Levels of background tropospheric $\mathrm{NO}_{2}$ measured by TROPOMI-ESA across India. Right panel: Map of India depicting GPS coordinates of data recorder stations in 4 metro cities; Upper left panel: On 15 March 2020 (before the lockdown); bottom-left: On 08 April 2020 (during the lookdown). 
the production of fertilizers, and closure of such enterprises has also reduced the emission of $\mathrm{NO}_{2}$. During the COVID-19 outbreak, significant reduction in the average level of $\mathrm{NO}_{2}$, by as much as $30 \%$ in Central China (NASA, 2020) and an approximately $40 \%$ reduction in Europe (CREA, 2020) have also been reported. In addition, an evident decrease of $\mathrm{NO}_{2}$ was also observed in recent studies from Brazil (Dantas et $a l .$, 2020), Italy, France, Spain and United States of America (Muhammad et al., 2020) on air quality during lockdown as a result of a decrease of the road transport and combustion of fossil fuels.

The mean concentration of $\mathrm{NH}_{3}$ had a significant reduction $(\mathrm{p}<0.05)$ only in Kolkata $(31.5 \%)$ and non-significant reduction in Delhi and Chennai. The data for $\mathrm{NH}_{3}$ was unavailable from Mumbai station. The results of the present study are in concordance with previous study where the reduction in level of $\mathrm{NH}_{3}$ was found during COVID-19 lock down in Delhi (Mahato et al., 2020), which has been attributed due to the shutdown of transport, of which petrol engine vehicles contributed a major share of urban $\mathrm{NH}_{3}$ in India (Kean et al., 2000; Mahato et al., 2020).

The mean concentration of $\mathrm{SO}_{2}$ was found to be significantly reduced $(\mathrm{p}<0.05)$ during lockdown period in Kolkata $(22.8 \%)$ and Chennai $(5.0 \%)$. However, the $\mathrm{SO}_{2}$ concentration had non-significant reduction in Delhi $(8.9 \%)$ and on contrary, the concentration was found to increase in Mumbai. The levels of $\mathrm{SO}_{2}$ were found below the WHO limit of $20 \mu \mathrm{g} \mathrm{m}^{-3}$ daily mean at all sites, except for Mumbai. The burning of sulphur containing materials such as coal and oil are the major sources of $\mathrm{SO}_{2}$ (Jones and Harrison, 2011). The observed increase in Mumbai can be attributed to higher levels of $\mathrm{SO}_{2}$ even during the pre-lockdown phase owing to the presence of large number of coal power plants and oil and gas corporations in the area (The Asian Age, 2019). The significant reduction in wind speed in Mumbai, might have also impeded the dilution effect on $\mathrm{SO}_{2}$ concentration (Tasić et al., 2013). It is suggested that in urban environment, the increased concentrations of the air pollutants may be due to meteorological conditions that impede their dispersion in the atmosphere (Radaideh, 2017). The carbon monoxide (CO) emissions are considered as an effective tracer for air pollution, where the $\mathrm{CO}$ measurements can provide potentially valuable information on the intensity of various anthropogenic activities (Hanaoka and Masui, 2020). The mean concentration of CO in Delhi, Mumbai and Kolkata was observed to be decreased significantly $(\mathrm{p}<0.05)$ by $32.7 \%, 40.1 \%$ and $28.5 \%$, respectively, whereas, in Chennai it increased by $24.1 \%$ during the lockdown period. Alike in present study, the average concentration of $\mathrm{CO}$ has been found to be decreased by $25 \%$ in China and $6 \%$ worldwide during the lockdown period (Myllyvirta, 2020). However, the increase in $\mathrm{CO}$ concentration in Chennai might be correlated with much lower precipitation observed in this region during the study period (Skymet Weather Team, 2020).

The mechanisms for ground-level ozone $\left(\mathrm{O}_{3}\right)$ formation and depletion are complex and this secondary air pollutant is formed by photochemical reaction between oxides of nitrogen and volatile organic compounds (VOCs) emitted from natural sources and/or due to human activities (Pyrgou et al., 2018; Manisalidis et al., 2020). The various meteorological conditions such as high temperature, low relative humidity and high solar radiation are favourable for the surface ozone formation (Pawalak and Jarosławski, 2015). In the present study, the mean concentration of $\mathrm{O}_{3}$ was observed to be markedly increased ( $\mathrm{p}<0.05)$ in Delhi $(50.9 \%)$ and Chennai $(18.8 \%)$ and non-significant increase by $6.3 \%$ was noted in Kolkata. A significant reduction by $44.8 \%$ was observed in Mumbai during the lockdown phase. However, except for Chennai, the concentration of $\mathrm{O}_{3}$ at all sites was less than the WHO limit of $100 \mu \mathrm{g} \mathrm{m}^{-3}$ (8-hour mean) during the lockdown phase. The increase in $\mathrm{O}_{3}$ levels in all sites, except Mumbai, is in accordance with the increasing levels of ground level ozone discussed by various authors in previous studies (Jain and Shrama, 2020; Sicard et al., 2020, Xu et al., 2020). The lockdown phase which paved to complete stoppage of transport and industrial sector has been reported to extensively reduce the emission of $\mathrm{O}_{3}$ degrading compounds such as $\mathrm{NO}_{\mathrm{x}}$ (Monks et al., 2015; Collivignarelli et al., 2020). In India, transport and power sector are the major contributors of $\mathrm{NO}_{\mathrm{x}}$, primarily emitted through high temperature combustion of fuels in these sectors (Sharma et al., 2016), therefore, the eventual reduction in $\mathrm{NO}_{\mathrm{x}}$ emissions due to lockdown might have led to higher $\mathrm{O}_{3}$ concentrations (Sicard et al., 2020). Moreover, alike the other mega cities in the world, most of the cities in India are VOC limited (Wang et al., 2005; Sharma et al., 2016). The higher $\mathrm{O}_{3}$ concentration observed in the present study are in accordance with the earlier studies in Europe, where due to implementation of stringent lockdown measures, higher $\mathrm{VOC}-\mathrm{NO}_{\mathrm{x}}$ ratio resulted from more reduced $\mathrm{NO}_{\mathrm{x}}$ emissions than VOCs emissions (Sicard et al., 2020). As the anthropogenic emissions of $\mathrm{O}_{3}$ have reduced from the stoppage of fuel and biomass combustion and industrial emissions during lockdown, the biogenic VOC emissions might have also contributed to the higher $\mathrm{O}_{3}$ emissions during the daytime period (He et al., 2019). Furthermore, the increase in $\mathrm{O}_{3}$ concentrations can also be attributed to the onset of summers during the study period (Kumari and Toshniwal, 2020). Previously, it has also been reported that increase in insolation in the period from April to August has led to increase in $\mathrm{O}_{3}$ levels in India (Gorai et al., 2017). Ozone concentration in air also depends on the sunlight intensity and wind direction of the regions which are not covered in this study. Moreover, reduction in particulate matter concentrations which allows passage of more sunlight and concurrent increase in more photochemical activities can also contribute to higher $\mathrm{O}_{3}$ production (Dang and Liao, 2019; Li et al., 2019). On contrary to all other cities, Mumbai displayed significant reduction in Ozone, which needs to be addressed in the context of difference in meteorological parameters. Certain atmosphere conditions such as high relative humidity which is unfavourable for ozone formation was observed only in Mumbai (Pawalak and Jarosławski, 2015). However, detailed examination of other meteorological parameters like sunlight intensity and wind direction are beyond the scope of the present study.

Overall, during the lockdown period, Delhi and Kolkata displayed the most significant reduction in all the three prominent pollution parameters, $\mathrm{PM}_{2.5}, \mathrm{PM}_{10}$ and $\mathrm{NO}_{2}$ with respective reduction of $63.9 \%, 56.7 \%, 63.9 \%$ in Delhi and 
$53.6 \%, 34.2 \%, 65.8 \%$ in Kolkata. Whereas, Mumbai displayed significant reduction in $\mathrm{PM}_{2.5}$ and $\mathrm{NO}_{2}$ of $34.5 \%$ and $74.4 \%$, respectively and in Chennai, significant decrease was observed for $\mathrm{NO}_{2}$ of $29.3 \%$.

The emissions from transport, industry, power generation, biomass burning, construction works and dust are the mainstay of pollutants in the mega-cities of India. In Delhi, the transport sector alone is responsible for $41 \%$ of the total pollution and is also the main source for $\mathrm{PM}_{2.5}$ emissions, whereas, industrial pollution contributes about $18.6 \%$ to the bad air quality (Livemint, 2019). Among the study areas, the particulate matter pollution was found highest in Delhi, hence the lockdown has brought significant changes in particulate matter concentration. With regard to Mumbai, the Industrial capital of India, the major pollution sources are the industrial emissions from the small, medium, and heavy industries (Urban Emissions, 2018). This difference in source of emissions can be noted from the high $\mathrm{NO}_{2}$ and $\mathrm{SO}_{2}$ concentration in Mumbai as compared to other study areas. Kolkata's air pollution stands next to Delhi, as reported by WHO and United Nations Environment Program and vehicles contribute to around $60 \%$ of the emissions as indicated by high $\mathrm{PM}_{2.5}$ and $\mathrm{PM}_{10}$ emissions in Kolkata before the lockdown (Chakraborty, 2018). The city of Chennai host large commercial port and hence the freight movement of ships and on roads heavy duty trucks contribute significant $\mathrm{PM}_{2.5}$ emissions (Guttikunda et al., 2019).

Atmospheric pollution has been hypothesized to play crucial role among the various factors possibly involved in transmission dynamics of COVID-19 outbreak. Particulate matter, nitrogen dioxide, and carbon monoxide are most likely air pollutants to increase the prolonged existence of the virus particles under favourable climate conditions (Martelletti and Martelletti, 2020). Even a mild increase in long-term exposure to $\mathrm{PM}_{2.5}$ has been reported to elevate death rate due to COVID-19 (Wu et al., 2020). The environment particulate, $\mathrm{PM}_{10}$ particles may play crucial role in disease transmission by carrying the COVID viruses (Setti et al., 2020). It has been estimated that lockdown measures in India have been responsible for much lower cases than estimated of COVID-19 (Koshy, 2020; Ray et al., 2020). Along with decrease in air pollution, lockdown implementation has also helped in lowering down the basic reproduction number $\left(\mathrm{R}_{0}\right)$ of the disease by reducing the contact rate. Further aggressive media awareness on social distancing, good hygiene and behavioral changes during interactions (e.g., no handshakes) impede the transmission of disease.

The meteorological parameters such as wind speed and direction, temperature and vertical thermal gradient, atmospheric pressure, relative humidity, rain and solar radiation influence the diffusion and dilution capabilities of particles, the gas-particle conversion process, and secondary formation of particles (Fortelli et al., 2016; Xu et al., 2018). Among the observed meteorological parameters, average temperature was found to significantly increase in Delhi by $2.0^{\circ} \mathrm{C}$, Mumbai by $1.5^{\circ} \mathrm{C}$ and Kolkata by $4.7^{\circ} \mathrm{C}$, whereas, in Chennai a non-significant increase of $0.7^{\circ} \mathrm{C}$ was observed (Table S2). In Mumbai, humidity significantly increased by $22.1 \%$ and wind speed significantly reduced by $17.0 \%$ during the study period, non-significant changes were observed in humidity and wind speed in all other cities. Except for Delhi, the atmospheric pressure reduced significantly in all other metropolitan cities under the study. Apart from Western disturbances which resulted in rain throughout India except for the Southern peninsula, no other violent meteorological phenomena were observed in India during the study period.

Undoubtedly, weather conditions and pollutant levels have strong linkage that may obscure the variation in emission levels over different cities (Radaideh, 2017). Meteorological variability was found to account for $40-70 \%$ of ozone variability and $20-50 \%$ of particulate matter variability (Wise and Comrie, 2005). The meteorological normalization to detect interventions in air quality parameters is beyond the scope of the paper.

Most of the Indian cities are growing by population as well as in their zones. Therefore, it is important to promote safe and clean atmosphere for the upliftment of the public health. In the present study, the pollutant limits of the World Health Organization (WHO) have been used as benchmarks which are more stringent when compared to the Indian national guidelines. Environmental health experts have timely demanded to revise appropriately these guidelines in parity with the WHO's; however, socio-economic and environmental issues remain the main counter-argument for the same. The results of the present study found that the lockdown measures might have great effect on lowering down the key air pollutants in the country. Thereby, it reflects the vast potential for the control of pollution in Indian cities that can be achieved postCOVID-19 phase by managing anthropogenic sources of the pollutants through multi-pronged coordinated approaches which must include novel technological interventions and stringent regulations along with public awareness.

\section{CONCLUSION}

Air quality can be expected to have further improved due to more strict actions to curtail the human movement and continuous closure of industries. Though the lockdown measures had drastic effect on the economy, at the same time it led to a considerable decrease in public traffic and emission from production units, and consequently, has resulted in low levels of urban air pollution. Since in India, before lockdown period, all the major four metropolitan cities indicated significant air pollution above the threshold limits of WHO air pollutant limits, thereby, without lockdown measures the huge population might have been exposed to much higher risk of disease transmission. Moreover, the lockdown has been attributed immensely positive public health as well as environmental impact, in this context, the lesson must be carried away by the policy makers for intermittent healing of the environment by such measures along with the sustainable development activities in developing countries.

\section{ACKNOWLEDGEMENTS}

Authors are thankful to the Guru Angad Dev Veterinary and Animal Sciences University, Ludhiana for providing necessary help to write the manuscript. 


\section{DISCLAIMER}

The authors declare that they have no known competing interests that could have appeared to influence the work reported in this paper.

\section{SUPPLEMENTARY MATERIAL}

Supplementary data associated with this article can be found in the online version at https://doi.org/10.4209/aaqr.2 020.05.0209

\section{REFERENCES}

Balakrishnan, K., Dey, S., Gupta, T., Dhaliwal, R.S., Brauer, M., Cohen, A.J., Stanaway, J.D., Beig, G., Joshi, T.K., Aggarwal, A.N. and Sabde, Y. (2019). The impact of air pollution on deaths, disease burden, and life expectancy across the states of India: The Global Burden of Disease Study 2017. Lancet Planet. Health 3: e26-e39. https://doi.org/10.1016/S2542-5196(18)30261-4

Barzeghar, V., Sarbakhsh, P., Hassanvand, M.S., Faridi, S. and Gholampour, A. (2020). Long-term trend of ambient air $\mathrm{PM}_{10}, \mathrm{PM}_{2.5}$, and $\mathrm{O}_{3}$ and their health effects in Tabriz city, Iran, during 2006-2017. Sustainable Cities Soc. 54: 101988. https://doi.org/10.1016/j.scs.2019.101988

CensusInfo India (2011). http://www.dataforall.org/dashb oard/censusinfo/

Centre for Research on Energy and Clean Air (CREA) (2020). 11,000 air pollution-related deaths avoided in Europe as coal, oil consumption plummet. https://energy andcleanair.org/air-pollution-deaths-avoided-in-europeas-coal-oil-plummet/

Chakraborty, P. (2018, December 12). Kolkata's polluted air. The Statesman. https://www.thestatesman.com/opini on/kolkatas-polluted-air-1502715685.html

Chen, Q.X., Huang, C.L., Yuan, Y. and Tan, H.P. (2020). Influence of COVID-19 event on air quality and their association in mainland China. Aerosol Air Qual. Res. 20: 1541-1551. https://doi.org/10.4209/aaqr.2020.05.0024

Collivignarelli, M.C., Abbà, A., Bertanza, G., Pedrazzani, R., Ricciardi, P. and Miino, M.C. (2020). Lockdown for CoViD-2019 in Milan: What are the effects on air quality? Sci. Total Environ. 732: 139280. https://doi.org/10.1016/ j.scitotenv.2020.139280

Dang, R. and Liao, H. (2019). Radiative forcing and health impact of aerosols and ozone in China as the consequence of clean air actions over 2012-2017. Geophys. Res. Lett. 46: 12511-12519. https://doi.org/10.1029/2019GL084605

Dantas, G., Siciliano, B., França, B.B., da Silva, C.M. and Arbilla, G. (2020). The impact of COVID-19 partial lockdown on the air quality of the city of Rio de Janeiro, Brazil. Sci. Total Environ. 729: 139085. https://doi.org/1 0.1016/j.scitotenv.2020.139085

Elperin, T., Fominykh, A., Krasovitov, B. and Vikhansky, A. (2011). Effect of rain scavenging on altitudinal distribution of soluble gaseous pollutants in the atmosphere. Atmos. Environ. 45: 2427-2433. https://doi.org/10.1016/j.atmose nv.2011.02.008
Faridi, S., Yousefian, F., Niazi, S., Ghalhari, M.R., Hassanvand, M.S. and Naddafi. K. (2020). Impact of SARS-CoV-2 on ambient air particulate matter in Tehran. Aerosol Air Qual. Res. 20: 1805-1811. https://doi.org/10. 4209/aaqr.2020.05.0225

Fortelli, A., Scafetta, N. and Mazzarella, A. (2016). Influence of synoptic and local atmospheric patterns on $\mathrm{PM}_{10}$ air pollution levels: A model application to Naples (Italy). Atmos. Environ. 143: 218-228. https://doi.org/10.1016/j. atmosenv.2016.08.050

Gorai, A.K., Tchounwou, P.B. and Mitra, G. (2017). Spatial variation of ground level ozone concentrations and its health impacts in an urban area in India. Aerosol Air Qual. Res. 17: 951-964. https://doi.org/10.4209/aaqr.2016.08.0 374

Gordon, T., Balakrishnan, K., Dey, S., Rajagopalan, S., Thornburg, J., Thurston, G., Agrawal, A., Collman, G., Guleria, R., Limaye, S. and Salvi, S. (2018). Air pollution health research priorities for India: Perspectives of the Indo-US Communities of Researchers. Environ. Int. 119: 100-108. https://doi.org/10.1016/j.envint.2018.06.013

Guo, L.C., Zhang, Y., Lin, H., Zeng, W., Liu, T., Xiao, J., Rutherford, S., You, J. and Ma, W. (2016). The washout effects of rainfall on atmospheric particulate pollution in two Chinese cities. Environ. Pollut. 215: 195-202. https://doi.org/10.1016/j.envpol.2016.05.003

Guttikunda, S.K., Nishadh, K.A. and Jawahar, P. (2019). Air pollution knowledge assessments (APnA) for 20 Indian cities. Urban Clim. 27:1 24-141. https://doi.org/10.1016/ j.uclim.2018.11.005

Hanaoka, T. and Masui, T. (2020). Exploring effective short-lived climate pollutant mitigation scenarios by considering synergies and trade-offs of combinations of air pollutant measures and low carbon measures towards the level of the $2^{\circ} \mathrm{C}$ target in Asia. Environ. Pollut. 261: 113650. https://doi.org/10.1016/j.envpol.2019.113650

He, Z.R., Wang, X.M., Ling, Z.H., Zhao, J., Guo, H., Shao, M. and Wang, Z. (2019). Contributions of different anthropogenic volatile organic compound sources to ozone formation at a receptor site in the Pearl River Delta region and its policy implications. Atmos. Chem. Phys. 19: 8801-8816. https://doi.org/10.5194/acp-19-8801-2019 IQAir (2019). World's most polluted cities $2019\left(\mathrm{PM}_{2.5}\right)$, Norway. https://www.iqair.com/world-most-polluted-cities

Jain, S. and Sharma, T. (2020). Social and travel lockdown impact considering coronavirus disease (COVID-19) on air quality in megacities of India: Present benefits, future challenges and way forward. Aerosol Air Qual. Res. 20: 1222-1236. https://doi.org/10.4209/aaqr.2020.04.0171

Jones, A.M. and Harrison, R.M. (2011). Temporal trends in sulphate concentrations at European sites and relationships to sulphur dioxide. Atmos. Environ. 45:873-882. https://doi.org/10.1016/j.atmosenv.2010.11.020

Kean, A.J., Harley, R.A., Littlejohn, D. and Kendall, G.R. (2000). On-road measurement of ammonia and other motor vehicle exhaust emissions. Environ. Sci. Technol. 34: 3535-3539. https://doi.org/10.1021/es991451q

Koshy, J. (2020, April 11). Coronavirus- Without lockdown, India would have seen over 8 lakh cases by April 15, says 
Health Ministry. The Hindu. https://www.thehindu.com/n ews/national/coronavirus-without-lockdown-india-wouldhave-seen-over-8-lakh-cases-by-april-15-says-health-mi nistry/article31319364.ece

Kumari, P. and Toshniwal, D. (2020). Impact of lockdown measures during COVID-19 on air quality-A case study of India. Int. J. Environ. Health Res. https://doi.org/10.10 80/09603123.2020.1778646

Li, K., Jacob, D.J., Liao, H., Shen, L., Zhang, Q. and Bates, K.H. (2019). Anthropogenic drivers of 2013-2017 trends in summer surface ozone in China. PNAS 116: 422-427. https://doi.org/10.1073/pnas.1812168116

Livemint (2019). Why is Delhi's air so toxic? https://www.livemint.com/news/india/why-is-delhi-s-airso-toxic-11572782475997.html

Mahato, S., Pal, S. and Ghosh, K.G. (2020). Effect of lockdown amid COVID-19 pandemic on air quality of the megacity Delhi, India. Sci. Total Environ. 730: 139086. https://doi.org/10.1016/j.scitotenv.2020.139086

Manisalidis, I., Stavropoulou, E., Stavropoulos, A. and Bezirtzoglou, E. (2020). Environmental and health impacts of air pollution: A review. Front. Public Health 8: 14. https://doi.org/10.3389/fpubh.2020.00014

Mannucci, P.M. and Franchini, M. (2017). Health effects of ambient air pollution in developing countries. Int. J. Environ. Res. Public Health. 14: 1048. https://doi.org/10. 3390/ijerph14091048

Marlier, M.E., Jina, A.S., Kinney, P.L. and DeFries, R.S. (2016). Extreme air pollution in global megacities. Curr. Clim. Change Rep. 2: 15-27. https://doi.org/10.1007/s40 641-016-0032-z

Martelletti, L. and Martelletti, P. (2020). Air pollution and the novel Covid-19 disease: A putative disease risk factor. SN Compr. Clin. Med. 2: 383-387. https://doi.org/10.100 7/s42399-020-00274-4

Monks, P.S., Archibald, A.T., Colette, A., Cooper, O., Coyle, M., Derwent, R., Fowler, D., Granier, C., Law, K.S., Mills, G.E. and Stevenson, D.S. (2015). Tropospheric ozone and its precursors from the urban to the global scale from air quality to short-lived climate forcer. Atmos. Chem. Phys. 15: 8889-8973. https://doi.org/10.5194/acp15-8889-2015

Muhammad, S., Long, X. and Salman, M. (2020). COVID19 pandemic and environmental pollution: A blessing in disguise? Sci. Total Environ. 728: 138820. https://doi.org/ 10.1016/j.scitotenv.2020.138820

Myllyvirta, L. (2020, February 19). Analysis: Coronavirus temporarily reduced China's $\mathrm{CO}_{2}$ emissions by a quarter. Carbon Brief. https://www.carbonbrief.org/analysis-coro navirus-has-temporarily-reduced-chinas-co2-emissionsby-a-quarter

National Aeronautics and Space Administration (NASA) (2020). https://earthobservatory.nasa.gov/images

Pawlak, I. and Jarosławski, J. (2015). The influence of selected meteorological parameters on the concentration of surface ozone in the central region of Poland. Atmos. Ocean 53: 126-139. https://doi.org/10.1080/07055900.2 014.969189

Pyrgou, A., Hadjinicolaou, P. and Santamouris, M. (2018).
Enhanced near-surface ozone under heatwave conditions in a Mediterranean island. Sci. Rep. 8: 9191. https://doi.org/ 10.1038/s41598-018-27590-z

Radaideh, A.J. (2017). Effect of meteorological variables on air pollutants variation in arid climates. J. Environ. Anal. Toxicol. 7: 2161-0525. https://doi.org/10.4172/2161-052 5.1000478

Ray, D., Salvatore, M., Bhattacharyya, R., Wang, L., Mohammed, S., Purkayastha, S., Halder, A., Rix, A., Barker, D., Kleinsasser, M. and Zhou, Y. (2020). Predictions, role of interventions and effects of a historic national lockdown in India's response to the COVID-19 pandemic: Data science call to arms. medRxiv 2020.04.15.20067256. https://doi.org/10.1101/2020.04.1 5.20067256

Sergeant, E.S.G. (2018). Epitools epidemiology calculator. Ausvet. http://epitools.ausvet.com.au

Setti, L., Passarini, F., De Gennaro, G., Barbieri, P., Perrone, M.G., Piazzalunga, A., Borelli, M., Palmisani, J., Di Gilio, A., Piscitelli, P. and Miani, A. (2020). The Potential role of Particulate Matter in the Spreading of COVID-19 in Northern Italy: First Evidence-based Research Hypotheses. medRxiv 2020.04.11.20061713. https://doi.org/10.1101/2 020.04.11.20061713

Sharma, S.K. and Mandal, T.K. (2017). Chemical composition of fine mode particulate matter $\left(\mathrm{PM}_{2.5}\right)$ in an urban area of Delhi, India and its source apportionment. Urban Clim. 21: 106-122. https://doi.org/10.1016/j.uclim. 2017.05.009

Sharma, S., Zhang, M., Gao, J., Zhang, H. and Kota, S.H. (2020). Effect of restricted emissions during COVID-19 on air quality in India. Sci. Total Environ. 728: 138878. https://doi.org/10.1016/j.scitotenv.2020.138878

Sicard, P., De Marco, A., Agathokleous, E., Feng, Z., Xu, X., Paoletti, E., Rodriguez, J.J.D. and Calatayud, V. (2020). Amplified ozone pollution in cities during the COVID-19 lockdown. Sci. Total Environ. 735: 139542. https://doi.org/10.1016/j.scitotenv.2020.139542

Skymet Weather Team (2020, April). Weather highlights of March 2020: India rain surplus by $47 \%$ in March. https://www.skymetweather.com/content/weather-newsand-analysis/weather-highlights-of-march-2020-indiarain-surplus-by-47-in-march/

Tasić, V., Kovačević, R. and Milošević, N. (2013). Investigating the impacts of winds on $\mathrm{SO}_{2}$ concentrations in Bor, Serbia. J. Sustainable Dev. Energy Water Environ. 1: 141-151. https://doi.org/10.13044/j.sdewes.2013.01.0010

The Asian Age (2019, August 20). Maharashtra has most hotspots of $\mathrm{SO}_{2}$ : Greenpeace. https://www.asianage.com/ metros/mumbai/200819/maharashtra-has-most-hotspotsof-so2-greenpeace.html

Tobías, A., Carnerero, C., Reche, C., Massagué, J., Via, M., Minguillón, M.C., Alastuey, A. and Querol, X. (2020). Changes in air quality during the lockdown in Barcelona (Spain) one month into the SARS-CoV-2 epidemic. Sci. Total Environ. 726: 138540. https://doi.org/10.1016/j.sci totenv.2020.138540

Urban Emissions (2019). City - Mumbai (Maharashtra, India). https://urbanemissions.info/india-apna/mumbai-india/ 
Veefkind, J.P., Aben, I., McMullan, K., Förster, H., De Vries, J., Otter, G., Claas, J., Eskes, H.J., De Haan, J.F., Kleipool, Q. and Van Weele, M. (2012). TROPOMI on the ESA Sentinel-5 Precursor: A GMES mission for global observations of the atmospheric composition for climate, air quality and ozone layer applications. Remote Sens. Environ. 120: 70-83. https://doi.org/10.1016/j.rse.2 011.09.027

Wang, Q.G., Han, Z.W. and Higano, Y. (2005) An inventory of nitric oxide emissions from soils in China. Environ. Pollut. 135: 83-90. https://doi.org/10.1016/j.envpol.2004. 10.007

Wise, E.K. and Comrie, A.C. (2005). Meteorologically adjusted urban air quality trends in the Southwestern United States. Atmos. Environ. 39: 2969-2980. https://doi.org/10.1016/j.atmosenv.2005.01.024

World Health Organization (WHO) (2018). Ambient (outdoor) air pollution. https://www.who.int/news-room/fact-sheet s/detail/ambient-(outdoor)-air-quality-and-health

World Health Organization (WHO) (2020a). Air pollution: Health impacts. https://www.who.int/airpollution

World Health Organization (WHO) (2020b). Coronavirus disease 2019 (COVID-19): Situation report, 107. World Health Organization. https://apps.who.int/iris/handle/106 $65 / 332061$

Wu, X., Nethery, R.C., Sabath, B.M., Braun, D. and Dominici, F. (2020). Exposure to air pollution and COVID-19 mortality in the United States. medRxiv 2020.04.05.20054502. https://doi.org/10.1101/2020.04.0 5.20054502

Xu, K., Cui, K., Young, L.H., Wang, Y.F., Hsieh, Y.K., Wan, S. and Zhang, J. (2020). Air quality index, indicatory air pollutants and impact of COVID-19 event on the air quality near central China. Aerosol Air Qual. Res. 20: 1204-1221. https://doi.org/10.4209/aaqr.2020.04.0139

Xu, Y., Xue, W., Lei, Y., Zhao, Y., Cheng, S., Ren, Z. and Huang, Q. (2018). Impact of meteorological conditions on $\mathrm{PM}_{2.5}$ Pollution in China during winter. Atmosphere 9: 429. https://doi.org/10.3390/atmos9110429

Received for review, May 9, 2020

Revised, July 4, 2020

Accepted, August 12, 2020 